\title{
PEMBUATAN PROPOSAL BISNIS GUNA MENANAMKAN MINAT BERWIRAUSAHA PADA SISWA MTS NURUL HIKMAH KABUPATEN BEKASI
}

\author{
Loecita Sandiar ${ }^{1^{*}}$, Dwi Narsih ${ }^{2}$ \\ ${ }^{1}$ Program Studi Pendidikan Ekonomi, FIPPS, Universitas Indraprasta PGRI Jakarta \\ ${ }^{21}$ Program Studi Pendidikan Ekonomi, FIPPS Universitas Indraprasta PGRI Jakarta \\ * Penulis Korespodensi : loecitasandir@gmail.com,dwipunya@gmail.com
}

\begin{abstract}
Abstrak
Tingginya minat berwirausaha akan melahirkan entrepreneur-entrepreneur muda yang memiliki visi yang jelas di masa depan, kreativitas serta inovasi yang tinggi dalam segala bidang. Mereka akan menjadi lebih mandiri, kreatif, dan inovatif dalam menciptakan peluang bisnis baru dan penemuan-penemuan baru. Masalah pengangguran terdidik akan dapat teratasi karena keluaran (output) dari hasil pendidikan kewirausahaan adalah calon-calon entrepreneur muda berbakat yang tidak lagi menjadi pencari kerja (job seeker) tetapi telah menjadi pencipta lapangan pekerjaan (job maker). Secara parsial, hasil pengujian hipotesis menunjukkan bahwa variabel subjective norms tidak memiliki pengaruh yang signifikan terhadap minat berwirausaha. Norma subjektif (subjective norms) merepresentasikan dukungan yang diberikan oleh orang-orang terdekat ketika responden akan memilih berwirausaha sebagai salah satu pilihan karir. Pengabdian masyarakat diadakan selama 3 bulan. Kegiatan diadakan di MTS Nurul ikmah Bekasi. Hasil yang dicapai siswa lebih mengenal cara tahapan berwirasuaha, dan berhati - hati serta cermat dalam merencanakan suatu bisnis / usaha.

Kata Kunci : Proposal Bisnis, Siswa Mts
\end{abstract}

\section{ABSTRACT}

The high interest in entrepreneurship will give birth to young entrepreneurs who have a clear vision of the future, high creativity and innovation in all fields. They will become more independent, creative and innovative in creating new business opportunities and new discoveries. The problem of educated unemployment will be overcome because the outputs of the results of entrepreneurship education are prospective talented young entrepreneurs who are no longer job seekers (job seekers) but have become job creators (job makers). Partially, the results of hypothesis testing indicate that the variable subjective norms do not have a significant effect on entrepreneurial interest. Subjective norms represent the support given by the people closest to them when the respondent will choose entrepreneurship as a career choice. Community service is held for 3 months. The activity was held at MTS Nurul ikmah Bekasi. The results achieved by students are more familiar with the stages of entrepreneurship, and careful and careful in planning a business / business.

Key Word : Business proposal, Mts Student 


\section{Pendahuluan}

Fenomena rendahnya minat dan motivasi pemuda Indonesia untuk berwirausaha dewasa ini menjadi pemikiran serius berbagai pihak, baik pemerintah, dunia pendidikan, dunia industri, maupun masyarakat. Berbagai upaya dilakukan untuk menumbuhkan jiwa kewirausahaan terutama merubah mindset para pemuda yang selama ini hanya berminat sebagai pencari kerja (job seeker) apabila kelak menyelesaikan sekolah atau kuliah mereka. Hal ini merupakan tantangan bagi pihak sekolah dan perguruan tinggi sebagai lembaga penghasil lulusan.Hasil pengujian hipotesis menunjukkan bahwa pendidikan kewirausahaan berpengaruh signifikan terhadap minat berwirausaha. Pendidikan kewirausahaan yang dimaksudkan adalah proses pembelajaran untuk mengubah sikap dan pola pikir mahasiswa terhadap pilihan karier berwirausaha. Dengan demikian siswa yang telah menempuh pendidikan SMA akan memiliki nilai-nilai hakiki dan karakteristik kewirausahaan sehingga akan meningkatkan minat serta kecintaan mereka terhadap dunia kewirausahaan.

Tingginya minat berwirausaha akan melahirkan entrepreneur-entrepreneur muda yang memiliki visi yang jelas di masa depan, kreativitas serta inovasi yang tinggi dalam segala bidang. Mereka akan menjadi lebih mandiri, kreatif, dan inovatif dalam menciptakan peluang bisnis baru dan penemuan-penemuan baru. Masalah pengangguran terdidik akan dapat teratasi karena keluaran (output) dari hasil pendidikan kewirausahaan adalah calon-calon entrepreneur muda berbakat yang tidak lagi menjadi pencari kerja (job seeker) tetapi telah menjadi pencipta lapangan pekerjaan (job maker). Secara parsial, hasil pengujian hipotesis menunjukkan bahwa variabel subjective norms tidak memiliki pengaruh yang signifikan terhadap minat berwirausaha. Norma subjektif (subjective norms) merepresentasikan dukungan yang diberikan oleh orang-orang terdekat ketika responden akan memilih berwirausaha sebagai salah satu pilihan karir. Norma subjektif tidak memiliki pengaruh terhadap minat berwirausaha, dengan demikian tekanan sosial dari pihak kelurga tidak menjadikan hambatan bagi seseorang untuk memulai karier sebagai wirausaha. Tekanan sosial kemungkinan menurun disebabkan karena sudah maraknya programprogram kompetisi kewirausahaan yang dimotori oleh beberapa bank swasta nasional dan perusahaan BUMN sehingga perlahan-lahan mulai mengubah mindset masyarakat bahwa menjadi seorang entrepreneur juga merupakan pilihan karier yang menguntungkan dari segi ekonomi dan sosial. Beberapa faktor psikologis yang membentuk sikap negatif masyarakat terhadap profesi wirausaha selama ini antara lain sifat agresif, exspansif, bersaing, egois, tidak jujur, kikir, sumber penghasilan tidak stabil, kurang terhormat, pekerjaan rendah, dan sebagainya. Pandangan semacam ini dianut oleh sebagian orang sehingga mereka tidak tertarik menekuni profesi sebagai wirausahawan. (Siswoyo, 2009). 


\section{Metode}

Metode kegiatan yang digunakan kepada peserta didik setelah diberikan penyuluhan maka selanjutnya akan diberi test langsung guna mengetahui pembuatan proposal. Berikut ini adalah tahapan pelatihan yang dilakukan:

1. Tahap Persiapan

Adapun tahap-tahap awal yang kami lakukan dalam pelatihan meliputi:

a.Survei awal, pada tahap ini dilakukan di Mts Nurul Hikmah, Kabupaten Bekasi

; Setelah survei maka ditetapkan lokasi pelaksanaan dan sasaran peserta kegiatan

Penyusunan bahan dan materi pelatihan yang meliputi, slide dan makalah untuk peserta kegiatan;

2. Tahap Pelaksanaan Pelatihan

Pada tahap ini akan menjelaskan tata cara pembuatan proposal bisnis ,agar dapat mengerti perencanaan bisnis.

\section{Tahap Pelatihan}

Untuk melaksanakan kegiatan ini digunakan beberapa metode pelatihan, yaitu: a. Metode Penyuluhan Metode ini dipilih untuk memberikan penjelasan bagaimana membuat proposl dengan baik

\section{Hasil dan Pembahasan}

Penyuluhan dan kegiatan penjelasan pembuatan proposal bisnis, dilaakukan atas kerjasama para orang tua dan guru serta kepala sekolah. Siswa diperkenalkan dengna baik, bagaiman mereka merencanakan suatu usaha. Siswa dierkenalkan bagaiman membuat proposal singkat, dengan bantuan penyusunan tim pengabdian masyarakat.

Adapun bagian penyusunan proposal yang akan di pandu oleh tim pengabdian kepada masyarakat adalah, pendahuluan, alasan bisnis, , anggaran dan penutup. Untuk pembagian tugas, per tim pengabdian kepada masysrkat menyesesuaikan pada jadwal sebagai berikut :

No

\begin{tabular}{c|c|c}
\hline 1 & Pendahuluan & 30 menit \\
\hline 2 & Alasan Bisnis & 55 \\
\hline 3 & Penentuan tingkat harga & 30 \\
\hline 4 & Penyusunan Anggaran & 30 \\
\hline
\end{tabular}




\begin{tabular}{c|c|c|}
\hline & Penutup & 20 \\
\hline & & \\
\hline & Jumlah & 165 menit \\
\hline
\end{tabular}

Sumber : Laporan Tim 2019

Pada tabel diatas dapat dilihat bahwa, total penyuluhan selama 165 menit, tim membagai tugas kedalam tiga pertemuan. Tim bergantian mengisi penyuluhan dan memberikan penjelasan agar siswa dapat mengerti. Kegiatan ini dilaksanakan secara bertahap. Tim memberikan penjelasan kepada siswa tentang penyusunan proposal bisnis, dalam rangka memperkenalkan kewirausahaan. Para siswa ditekankan untuk melatih dan membuat proposal tersebut. Siswa diharapkan mensurvei lokasi bisnis dan, memahami langkah demi langkah tahapan bisnis tersebut.

Pada tahap pembuatan pendahuluan siswa, dibantu agar paparan alasan perencanaaan bisnis itu jelas. Sesuai dengan eadaan real dan tidak dibuat - buat. Sebagai contoh tim merangkum beberapa usaha yang akan dikerjakan. Tim hanya mengambil beberapa contoh bidang usaha yang akan direncanakan para siswa, dan hal ini patut diapresiasi, karena mereka sudah berani merencanakan satu usaha kewirausahaan baik pribadi atau berkelompok, adapun bidangnya sebagai berikut :

Tabel. 1. Tabel Perencanaan Bisnis

\begin{tabular}{lll}
\hline No & \multicolumn{1}{c}{ Bidang Usaha/Modal } & Sasaran Pasar \\
\hline 1. & Jual Kripik Tempe/Rp.500.000 & Pasar dan Sekolah SD \\
2. & Minuman Jus/Rp.1.000.000 & Area Puskesmas \\
3. & Mainan Anak- anak/Rp.400.000 & Depan Sekolah TK \\
\hline
\end{tabular}

Pada tabel diatas, para siswa sudah merencanakan usaha tersebut. Namun masih ada yang belum menentukan bidang usahanya. Hal ini disebabkan masih takut, akan menanggung rugi jika tidak laku. Tim memberikan penjelasan, bahwa resiko akan ada, namun patut dicoba, agar siswa terlatih, dan terbiasa agar dapat berani menjalankan usaha tersebut.

Siswa yang akan menjalankan usaha tersebut, dapat menjadi contoh dan motivasi teman yang lain yang belum menetapkan bidang atau jenis usaha tersebut. 
Setelah diisi ,maka tim dapat menyimpulkan bahwa sebagian siswa masih kurang berminat dalam berusaha / berwirausaha.

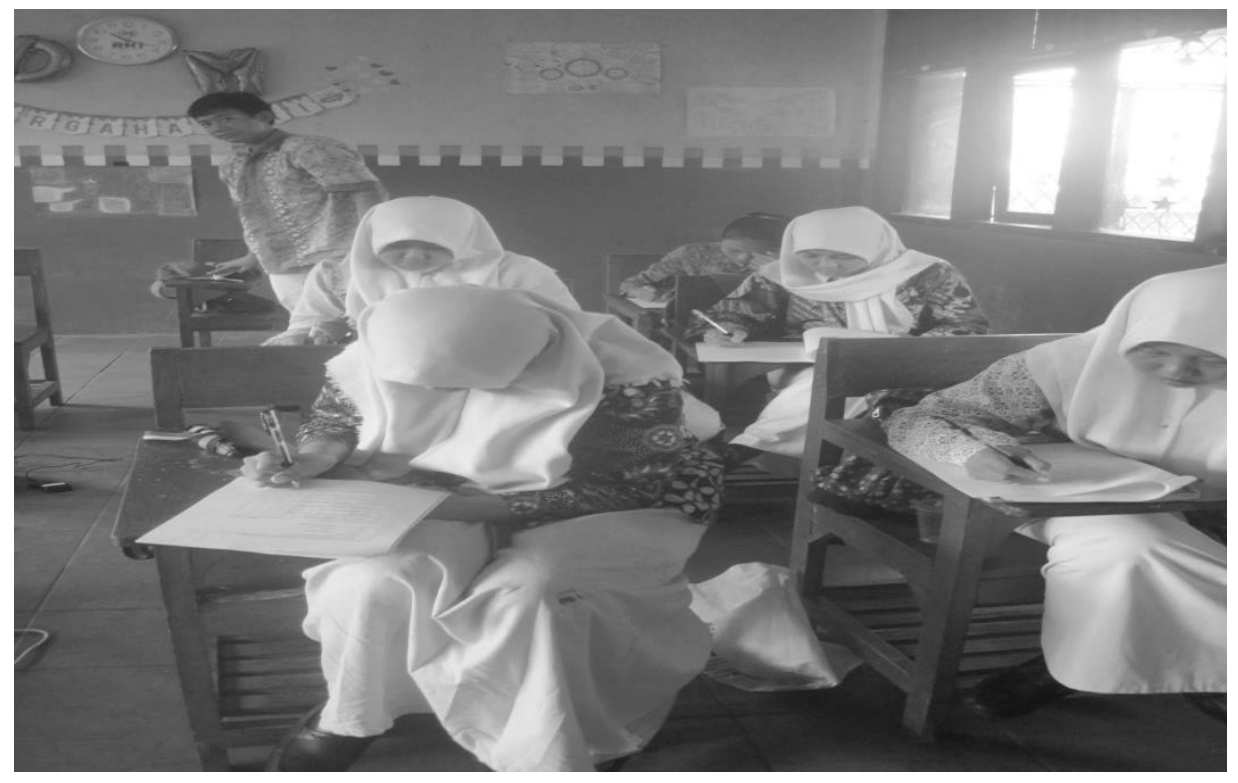

Gambar 1. Gambar pengisian Angket

Siswa sedang mengisi angket dan kesan dan pesan pada kegiatan pengabdian masyarakat. Setelah diisi ,maka tim dapat menyimpulkan bahwa paa siswa masih kurang berminat dalam berusaha / berwirausaha

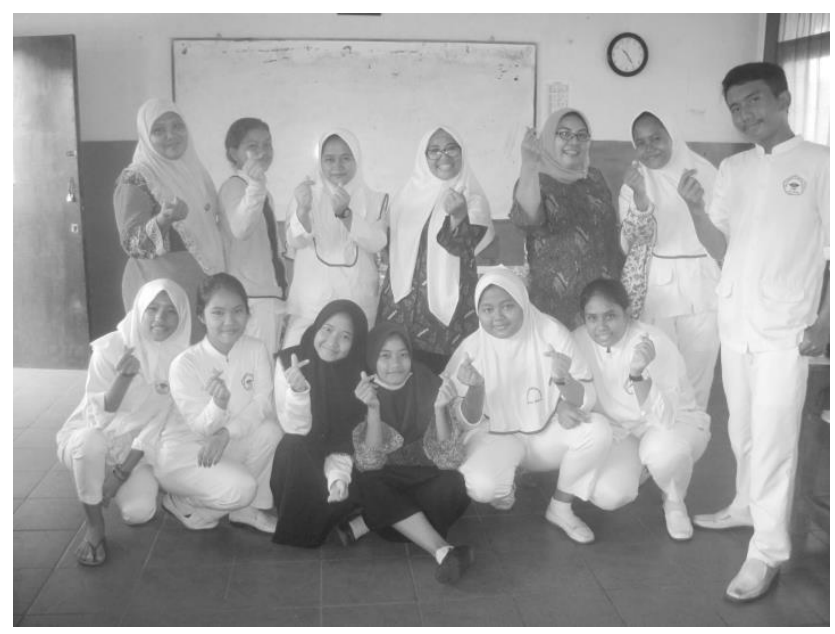

Gambar.2. Siswa menyelesaikan sesi akhir pelatihan 
Pada sesi akhir para siswa berfoto bersama tim , mereka diberikan latihan dan manajemen resiko kerugian. Kesan yag dapat diambil dari para siswa kegiatan ini sangat baik dan membantu memperkenalkan para siswa akan pentingnya kewirausahaan. Para guru berpendapat agar program ini dapat di kembangkan lebih intensif. Tim berpendapat bahwa suatu usaha sangat memerlukan kerjasama yang baik, agar tujuan pengabdian kepada masyarakat dapat dirasakan oleh para siswa dan para orang tua nanti. Hasil tidak serta merta terlihat, namun masih diperlukan waktu yang panjang guna menanamkan minat berwirausaha para siswa tersebut.

\section{Simpulan}

Simpulan dari pelaksanaan pengabdian masyarakat di Mts Nurul HIkmah Kota Bekasi, sebagai berikut :

1. Pemberian penyuluhan penyusunan proposal sangat bermanfaat, untuk memperkenalkan langkah berwirausaha

2. Minat berwirausaha dan motivasi belajar dapat ditingkatkan dengan pemberian penyuluhan tentang kewirausahaan

3. Kemampuan memulai berusaha sangat penting, aga siswa berani membuka usaha meskipun belum berhasil. Para siswa dapat mengemangkan usaha, walaupun dengan modal minim, namun bisa merasakan ,bagaiman siswa mempunyai tanggung jawab untuk berusaha.

\section{A. SARAN}

Saran yang dapat diajukan adalah :

1. Program sekolah yang sudah direncanakan, dengan mengadakan les, dapat divariasikan dengan program lain, seperti super camp, kemah bersama dll, agar siswa tidak merasa jenuh dan monoton`

2. Siswa yang kurang mampu dalam akademik, dapat melakukan remedial

3. Pengabdian dapat menjadi dasar program kewirausahaan yang lain..

4. Pihak sekolah dapat menyediakan modal bahan bahan mentah yang lebih beragam, agar siswa dapat memulai usaha

5. Koperasi sekolah dapat di aktifkan kembali, agar siswa termotivasi berwirausaha. 
Pada pelaksanaan program pengabdian masyarakat, tim melihat adanya tim work yang baik antara siswa dan guru serta yayasan. Perencanaan yang baik dan matang dapat dilaksanakan dengan tepat dan terarah. Siswa terlatih untuk dapat melaksanakan tugas tugas kemanusian seperti membagikan daging kepada masyarakat sehingga timbul rasa empathi kepada sesamanya. Para siswa juga memberikan sumbangan uang untuk dapat berkurban. Kegiatan ini dapat memberikan rasa keikhlasan dan kesederhanaan siswa, agar mau hidup sederhana. Mereka juga akan mendapat rasa keberanian, karena mau berkorban demi orang lain.

\section{Ucapan Terima Kasih}

Pada kesempatan ini, para penulis mengucapkan terimakasih kepada semua pihak yang telah membantu kegiatan ini. Khususnya para guru dan orang tua yang dapat memberikan bantuan saran dan inovasinya.

\section{Daftar Pustaka}

Alifah, S., Narsih, D., \& Widiyarto, S. (2019). Pengaruh Metode Partisipatori Dan Minat Belajar Terhadap Kemampuan Berwirausaha Siswa Smk. Lectura: Jurnal Pendidikan, 10(1), 66-81.

Aristi, G., \& Rahwana, K. A. (2019). Upaya Meningkatkan Pemasaran Produk Umkm Dengan Memanfaatkan Katalog Produk Di Kelurahan Sukahurip Kecamatan Tamansari Kota Tasikmalaya. Journal of Empowerment Community (JEC), 1(1), 6-11

Darmanto,2017,Kewirausahaan dan UMKM, Depublish : Jakarta

Sunarmintyastuti, L., \& Widiyarto, S. (2019). Pelatihan Pembuatan Prakarya Dalam Rangka Meningkatkat Minat Berwirausaha Siswa Mts. Matappa: Jurnal Pengabdian Kepada Masyarakat, 2(2)

Sunarya PO,dkk ,2011, Kewirausahaan, Andi Publisher : Jakarta.

Siswoyo, B. B. (2009). Pengembangan jiwa kewirausahaan di kalangan dosen dan mahasiswa. Jurnal ekonomi bisnis, 14(2), 35-45.

Vernia, D. M. (2018). Faktor-Faktor Yang Mempengaruhi Intensi Berwirausaha Siswa Kelas XI SMK Mitra Bakti Husada Bekasi. Lectura: Jurnal Pendidikan, 9(2), 105-114. 
Vernia, D. M. (2019). Peranan Lingkungan Sosial Dan Pendidikan Kewirausahaan Terhadap Minat Berwirausaha Siswa Kelas Xi Smk Cahaya Prima Jakarta. Jurnal Dimensi Pendidikan Dan Pembelajaran, 7(1), 30-36. 